\title{
Determinants of adoption of drought adaptations among vegetable growers in Florida
}

\author{
E.A. van Dijl, K.A. Grogan, and T. Borisova
}

\begin{abstract}
In the United States, Florida ranks second among states for both value and land area of vegetable production, but this production is affected by periodic droughts. Florida has experienced at least one severe and widespread drought every decade since 1900, and climate change projections show that meteorological droughts will occur more often in the future. While drought and climate change affect the supply side, population growth is expected to affect the demand side of water availability. Given these threats to future water availability, the adoption of drought adaptation and water conservation measures is of increasing importance in Florida. Using a 2013 survey of Florida vegetable growers, this paper addresses two main components of this problem. First, we assess the current rates of adoption of drought adaptation measures. Second, we analyze which factors influence or impede the adoption of these measures to provide policy recommendations to increase adoption in the future. We find low rates of adoption of adaptations, ranging from 13\% to 55\%, and factors determining who adopts a given adaptation vary by adaptation. Factors can have opposite effects on the probability of adoption across different adaptations. Unlike most previous work, we find that growers with more education have lower rates of adoption of water augmentation measures, and lack of land ownership does not necessarily impede adoption of adaptations with large initial investment.
\end{abstract}

Key words: agriculture—drought—drought adaptation—Florida—irrigation—water conservation

\begin{abstract}
Understanding adoption of drought adaptations among vegetable growers will become increasingly important as climate change and water demand threaten water availability. In the United States, Florida is the second largest producer of vegetables in terms of revenue (US $\$ 1.1$ billion) and crop area $(81,342$ ha $[201,000 \mathrm{ac}])$ (USDA NASS 2012), but periodic drought threatens this production. Florida has experienced at least one severe drought every decade since 1900 , and 2006 and 2007 were the state's driest years since 1932 (FDEP 2013). Climate change projections for Florida show that meteorological droughts will occur more often in the future (Karl et al. 2009). While drought and climate change affect the supply side, population growth will affect the demand side of water availability. Between 1990 and 2005, withdrawals for public supply increased $32 \%$, driven by population growth (Marella 2008). Florida's population
\end{abstract}

late fall, winter, and spring when Florida's production is sometimes the only supply in the United States (Freeman 2014). While this timing is good from a market perspective, its occurrence during the drier months can be problematic.

Agricultural water use accounts for $40 \%$ of all water use in Florida, with almost half of agricultural water coming from groundwater (Marella 2008). Excessive groundwater pumping by public suppliers and agricultural producers has been linked with saltwater intrusion, and a large proportion of the state is classified as "water resource caution areas" that currently have or are projected to have critical water supply problems within the next 20 years (FDEP 2011).

Several incentives exist at the state and national levels to encourage adoption of water conserving practices. Nationally, the USDA operates the Environmental Quality Incentives Program (EQIP), which can provide up to ten years and US $\$ 450,000$ in conservation investments for the adoption of Irrigation Water Management Plans (USDA NRCS 2014). At the state level, the Florida Department of Agriculture and Consumer Services (FDACS) works with water management districts and water conservation districts to reimburse growers for $75 \%$ of costs, with funding caps ranging from US\$15,000 to US\$50,000, for implementation of agricultural best management practices (BMPs). On a smaller, local scale, Mini-FARMS (a smaller version of the Facilitating Agricultural Resource Management Systems program, which has a broader scope), implemented through the Southwest Florida Water Management District, reimburses growers for 75\% of expenses of water conservation projects, with a cap of US\$5,000 (SWFWMD 2010). At the water management district level, all five districts have cost share programs for their districts' water priorities.

Florida agricultural producers must obtain a consumptive use permit for their withdrawals. The one-time permit fee varies by district and broadly defined consumption categories, and the permit duration is either up to 20 years, or more than 20 years (FDEP

Elizabeth A. van Dijl is a master's of science candidate, Kelly A. Grogan is an assistant professor, and Tatiana Borisova is an assistant professor in the Department of Food and Resource Economics at the University of Florida, Gainesville, Florida. 
2014). Due to the coarse scale of use and the 20-year length of permits, these fees are unlikely to provide an incentive for water conservation. In contrast, water pumping costs can provide an incentive for conservation. These costs are a function of water table depth or distance to surface water source, the cost of fuel used for pumping, and the type of the pump. They vary by region as well as by grower within a region. As water becomes scarcer, these costs will further increase.

Possible Drought Adaptation Measures. There are three main categories of drought adaptation measures: (1) augmenting water supply at the farm level, (2) reducing on-farm water losses, and (3) improving irrigation planning. Within each category, measures achieve the same effects on water use through very different means and costs. The measures were chosen through discussions with extension agents and include measures advocated as BMPs for Florida vegetable growers and growers in general at the national level (FDACS 2005; Schaible and Aillery 2012). In most cases, limited adoption data exist, particularly at the crop or regional level. Tables 1 and 2 provide results from the USDA's 2013 Farm and Ranch Irrigation Survey. Most data are only available at the state level, due to confidentiality reasons, and contain all Florida crops, not just vegetable crops.

Supply Augmentation Measures. There are two primary supply augmentation measures: (1) irrigation tailwater recovery and (2) rainwater harvesting. Tailwater recovery systems collect and reuse irrigation water runoff. Constructing the system costs about US $\$ 370$ to US\$555 ha $\mathrm{ha}^{-1}$ (US\$150 to US\$225 $\mathrm{ac}^{-1}$ ) (Carman 2005). Tailwater recovery conserves more water combined with seepage or flood irrigation systems than more efficient irrigation systems since less water runs off with more efficient systems (FDACS 2005). In 2013 , only $0.8 \%$ of all agricultural land in Florida recovered tailwater (table 2).

In order to harvest rainwater, growers can collect water from their rooftops, and the collected water is stored underground or in basins or tanks. For uncovered reservoirs, evaporation reduces water yield. If a large tank or reservoir is used for storage and this displaces crops, this measure includes the opportunity cost of the space utilized for the storage, and this opportunity cost will be higher for more highly valued crops. Additionally, in

\begin{tabular}{lccc}
$\begin{array}{l}\text { Table } 1 \\
\text { Adoption of irrigation systems by Florida growers (USDA 2014). }\end{array}$ \\
\hline & \multicolumn{2}{l}{ Irrigated hectares under irrigation system (\%) } \\
\cline { 2 - 4 } Crop type & Gravity & Sprinkler & $\begin{array}{c}\text { Drip, trickle, } \\
\text { low-flow }\end{array}$ \\
\hline All & 42.2 & 27.8 & 47.6 \\
All vegetables & 25.4 & 30.5 & 44.1 \\
Selected vegetables & & & \\
$\quad$ Sweet corn & 46.8 & 40.6 & 12.6 \\
$\quad$ Tomatoes & 3.8 & 11.9 & 84.3 \\
$\quad$ Lettuce and romaine & - & 89.6 & - \\
$\quad$ Potatoes & 74.1 & 15.0 & 10.9 \\
Berries & 8.9 & 57.6 & 33.5 \\
Orchards & 5.1 & 6.9 & 88.0
\end{tabular}

drought years, this measure may be less effective due to less rainfall to harvest.

Water Loss Reduction Measures. A more efficient irrigation system is the primary way to reduce productive water losses. Other measures include land leveling, mulching, and alternative freeze protection. Irrigation systems, ranked from most efficient to least efficient, fall into three main categories (Smajstria et al. 2002):

1. Low volume or micro-irrigation (drip irrigation, microjet, and microsprinkler)

2. Sprinkler irrigation (traveling gun and overhead)

3. Gravity or surface irrigation (ridge, flood, furrow, and seepage)

The more efficient the system, the more yield can be achieved from the same amount of water applied. We focus on the adoption of micro-irrigation since it is the most efficient system, with application efficiencies reaching $90 \%$ to $95 \%$ of water applied (Dukes et al. 2010). Micro-irrigation allows for precise water distribution and electronic scheduling on large areas with smaller pumps relative to sprinkler systems (Dukes et al. 2010). The costs depend on the crop type, pipe thickness and material, and system lifespan. The initial investment is substantial, requiring US $\$ 1,235$ to US\$3,000 $\mathrm{ha}^{-1}$ (US\$500 to US $\$ 1,200 \mathrm{ac}^{-1}$ ) or more (Simonne et al. 2008), potentially lessening the likelihood of adoption by producers of crops with a low per hectare value.

Table 1 contains the percentage of irrigated agricultural land under each category of system for all crops, all vegetable crops, vegetable crops with available data, berries, and orchards. Relative to the other reported categories, a high percentage of tomato (Solanum lycopersicum) and orchard land is under micro-irrigation, while a low percent- age of sweet corn (Zea mays var. saccharata) and potatoes (Solanum tuberosum) are under micro-irrigation. Interestingly, studies have shown the efficacy and economic profitability of micro-irrigation for both tomatoes and potatoes (Rogers et al. 2014; Reyes-Cabrera et al. 2014), but adoption rates differ substantially across the two crops. This highlights the need to further analyze factors that affect adoption of efficient irrigation systems.

Water losses in irrigation can occur because of uneven terrain. Growers may need to overirrigate depressed areas to ensure sufficient moisture in raised areas. Land leveling conserves water by creating a uniform gradient that leads to more uniform water application and a reduction in water use. It also improves drainage and uniformity of crop growth and yield and reduces erosion (Öztekin 2013). Costs vary from US $\$ 125$ to US $\$ 990 \mathrm{ha}^{-1}$ (US $\$ 50$ to US $\$ 400 \mathrm{ac}^{-1}$ ), depending on the severity of the initial slope and the soil type (Texas Water Development Board 2005). About $2.2 \%$ of all agricultural hectares in Florida have been leveled (table 2).

Growers can apply mulches to reduce the evaporation of moisture from the soil, which results in elevated and more even soil moisture content. When using an organic material, mulches can also increase the soil organic matter content (Ramakrishna et al. 2006). Both organic and plastic mulches prevent or reduce weed growth. For plastic mulch, installation and removal costs about US\$860 to US\$1,730 $\mathrm{ha}^{-1}$ (US\$350 to US\$700 $\mathrm{ac}^{-1}$ ) (Shrefler and Brandenberger 2014).

Finally, one common method of freeze protection involves sprinkler irrigation. As the water applied freezes, it releases heat, warming the crop (Parsons and Boman 2013). However, alternative methods include heaters, wind machines, and covers, which 
do not use water (Lyrene and Williamson 2004). For crops that are not significantly affected by freeze or in regions where freezes are less frequent, this measure may not be a relevant option. For growers who already use sprinkler irrigation, using an alternative measure implies investing in additional equipment that may not be used very often in a warm state like Florida. A wind machine that can protect 4 ha $(10 \mathrm{ac})$ costs about US $\$ 30,000$, but the machine can be used for many years. Costs also include fuel to run the wind machine (Moss 2013; Williamson et al. 2012). Row covers cost US $\$ 2,100$ to US $\$ 2,480 \mathrm{ha}^{-1}$ (US\$850 to US $\$ 1,000 \mathrm{ac}^{-1}$ ) plus the cost of labor to cover and uncover the crops (Bielinski et al. 2011).

Irrigation Planning. Four primary measures are used to increase the efficacy of irrigation planning: (1) soil moisture sensors, (2) variable rate irrigation or irrigation scheduling, (3) on-farm weather stations, and (4) automatic irrigation.

Soil moisture sensors measure the soil moisture content and can feed into other planning methods. Optimizing the soil moisture for crops can reduce drought damage and increase yields and crop quality (De Pascale et al. 2011). Sensors are normally placed every $10 \mathrm{~cm}$ (3.9 in). Several types of sensor systems exist, but all measure some physical property that is correlated with soil moisture, such as electrical resistance (Naidu 2008). The two most common sensors, gypsum blocks and granular matrix sensors, range in cost from US $\$ 5$ to US $\$ 35$ each. To access the recorded data, a grower can use a handheld meter (US\$150 to US\$600) or a data logger (US\$60 to US\$500) (Morris 2006). About $6.8 \%$ of farms in Florida make use of soil moisture sensors (table 2). While soil moisture sensors can be combined with the three measures that follow, the following measures can also be used without soil moisture sensors.

Growers can use a weather station, either on their farm or in their region, to measure precipitation, wind, temperature, and/ or atmospheric moisture levels (Thessler et al. 2011). With an on-farm station, the information can be used with computer software to calculate the optimal irrigation moment. These technologies can reduce water applications and increase yields. If relying on a regional weather station, the grower incurs no cost except for the time cost of accessing and utilizing the data.

\section{Table 2}

Adoption of conservation measures by Florida growers (USDA 2014).

\begin{tabular}{lll}
\hline Conservation measure & $\begin{array}{l}\text { Total farms } \\
(\%)\end{array}$ & $\begin{array}{l}\text { Total hectares } \\
\text { (\%) }\end{array}$ \\
\hline Soil moisture sensors & 6.8 & - \\
Tailwater pits, diking, time limits, or alternative row irrigation & - & 0.8 \\
Precision leveling or zero-grading & - & 2.2
\end{tabular}

Variable-rate and scheduling irrigation involve applying water to crops at the right time and in the right amount. Scheduling often consists of grower judgment or a schedule of irrigation events based on previous seasons. Factors such as plant evaporation, soil characteristics, and root distribution are also important for irrigation scheduling (Locascio 2005). Growers can use soil moisture sensors or weather stations and these data can be combined with computer-based plant growth simulation models (Schaible and Aillery 2012). Another innovation is the use of variable-rate irrigation systems, which allow for different irrigation rates in different field sections (Delonge et al. 2007).

Lastly, growers can adopt automatic irrigation systems. For a soil moisture sensor-triggered system, when soil moisture reaches the trigger level set by the user, the system switches on the irrigation. However, it may take some time to understand how the soil moisture data should be used to determine irrigation decisions (Shortt and Verhallen 2011). Additionally, automatic irrigation systems can be used without soil moisture sensors, and could be trigged by weather station data or simply programmed by the grower.

Previous Work. There is a large body of literature on technology adoption in general, in both agricultural and nonagricultural contexts. Technology diffusion is one possible concept that could be applied here; adoption of a new product or technology spreads over time and space. The diffusion of adoption over time often follows an S-shaped curve, with a ceiling that may or may not be at $100 \%$ adoption (Rogers 1976). A seminal work in the agricultural literature on the theory of diffusion analyzes the adoption of hybrid corn over time (Griliches 1957). This analysis fits the increase in adoption to a logistic relationship for each corn-growing state. The rate of adoption as well as the adoption ceiling varies by state.

While technology diffusion occurs with any agricultural technology, data are often only available at one point in time, eliminating the ability to model the diffusion of adoption across time. Among literature using a snapshot of adoption, we focus our discussion on the adoption of efficient irrigation systems and climate/drought adaptations. Studies on adoption of efficient irrigation technologies at the farm level generally use logit/probit or multinomial logit models to explain adoption at one point in time as a function of the grower's expected utility compared with the utility obtained from the use of alternative technology (for examples, see Caswell and Zilberman 1985; Koundouri et al. 2006; Green et al. 1996; Carey and Zilberman 2002; Dinar et al. 1992; and Schuck et al. 2005). Many of these studies have focused on the western United States, in particular the San Joaquin Valley in California and in Colorado, areas with semiarid environments that often face water scarcity (Caswell and Zilberman 1985; Green et al. 1996; Dinar et al. 1992; Schuck et al. 2005). These studies identify characteristics of farms or growers that are associated with a higher probability of adopting the modern or more efficient technology. Growers with more education tend to be more likely to adopt modern irrigation technology (Koundouri et al. 2006; Schuck et al. 2005), and larger farms and/or larger fields are more likely to use modern irrigation than smaller farms (Green et al. 1996; Dinar et al. 1992; Schuck et al. 2005). Lastly, studies find that the probability of adoption varies by crop (Caswell and Zilberman 2002; Green et al. 1996; Dinar et al. 1992).

Other work has analyzed the adoption of some of the other measures that we consider, including rainwater harvesting and irrigation scheduling in China and Washington State, respectively (He et al. 2007; Leib et al. 2002). He et al. (2007) find that older growers are less likely to adopt rainwater harvesting, while growers with more education, larger on-farm labor forces, contact or training with research or extension groups, and access to credit were more likely to adopt rainwater harvesting. Leib et al. (2002) find that 27.5\% of surveyed growers in Washington used irrigation scheduling; the majority of these growers used irrigation scheduling with cen- 
ter-pivot irrigation. Almost all growers who reported using irrigation scheduling used observation of the feel and appearance of soil to determine when to irrigate instead of using more advanced technology.

Some analyses have jointly considered the adoption of more than one practice. Dorfman (1996) considers the adoption of improved irrigation and integrated pest management (IPM). He models the decision of apple (Malus domestica) growers in California, Michigan, New York, North Carolina, Oregon, Pennsylvania, Virginia, and Washington to adopt neither practice, one of the practices, or both. He finds that education increases the probability of adopting IPM and of simultaneously adopting both IPM and improved irrigation, but negatively affects the adoption of only irrigation. The amount of time the owner spends in offfarm employment decreases the probability of adopting both measures individually and simultaneously. Finally, total farm hectares increases the probability of adopting IPM and improved irrigation separately, but decreases the probability of adopting both simultaneously. Cooper and Keim (1996) model the decision of growers to adopt IPM, manure testing for nutrient content, legume crediting, division of standard applications of nitrogen (N) across time, and soil moisture testing. Their sample includes growers in the eastern Iowa and Illinois watershed, eastern Virginia and North Carolina, the coastal plain of Florida and Georgia, and Idaho. In general, they found high variability in the significance and effects of factors on adoption across the measures, so we focus on soil moisture sensors, which are most relevant for the following analysis. Higher farm income was negatively associated with soil moisture sensor adoption, and growers from Florida and Georgia were less likely to adopt soil moisture sensors than growers from other regions. Other variables, including farming experience, total farm size, and land value, did not significantly affect the probability of adoption.

In addition to Cooper and Keim (1996), limited analysis pertains to adoption of water conservation measures among Florida growers. One study surveyed fruit and vegetable growers, ornamental nurseries, and golf courses in Miami-Dade County to determine how their practices have changed since first beginning their operation and what conservation practices they have adopted (Munoz-Carpena et al. 2003).
Among their respondents, only six grew vegetables. Among vegetable growers, they find a transition from high volume overhead irrigation systems to drip irrigation. All vegetable respondents reported measuring rainfall and using weather data to schedule irrigation, $83.3 \%$ monitored soil moisture (using any method of monitoring), and half used mobile irrigation lab services. While this analysis considers several water conservation measures, the analysis only contains summary statistics of adoption and includes a small number of growers.

To the best of our knowledge, this paper is the first to analyze the adoption of a comprehensive list of drought adaptation and water conservation measures. As will be shown, some factors positively influence adoption of some measures while negatively influencing adoption of other measures. Considering only one measure or category of measures (e.g. irrigation systems), and then extrapolating results to other measures would be erroneous.

Additionally, much of the irrigation technology literature has focused on semiarid environments instead of environments like Florida that have plentiful rainfall in some years and droughts in other years. This type of climate may provide different incentives for growers to adopt drought adaptation measures than regions where water is always relatively scarce.

\section{Materials and Methods}

To determine the current rates of adoption of possible drought adaptation measures and to analyze the determinants of adoption, we utilized an online survey. The survey can be accessed at http://plaza.ufl.edu/kellyagrogan/kellyagrogan/Research_files/ drought $\% 20$ adaptations $\% 20$ survey.pdf. The survey was developed by discussions with extension agents and research on relevant adaptations and BMPs. The survey was pretested by three growers recruited through the Alachua County Farmers' Market and two from the University of Florida's Community Supported Agriculture program.

No centralized and accessible repository of contact information for all Florida growers exists, so we used three channels to recruit participants. It should be noted that lack of access to contact information for all growers is a common problem (the USDA itself lacks contact information for all growers [USDA NASS 2012]). The three channels we used to recruit participants are the following:
(1) the survey was distributed to growers who had expressed interest in BMPs with FDACS using methods described below, (2) the survey was distributed by the Florida Farm Bureau (FFB) in an e-mail to vegetable growers among their membership, and (3) 20 (out of 63) extension offices run by the University of Florida Institute of Food and Agricultural Sciences (IFAS) and several multicounty agents distributed the survey to growers for whom they had contact information. The extension offices were chosen due to location near major vegetable producing regions and willingness to distribute the survey. While not all targeted extension offices distributed the survey, the FFB and FDACS lists included counties not targeted by extension agents. We believe that the use of the three channels allowed us to identify the majority of Florida vegetable producers.

The largest group of respondents consists of growers whom we contacted directly through the FDACS list. These growers were sent a personalized invitation letter that contained an individual access code. In accordance with Dillman's (1991) recommendation, we used four carefully spaced mailings: (1) initial cover letter, (2) postcard follow-up one week after the original mailing, (3) second cover letter four weeks after the original mailing, and (4) second postcard reminder seven weeks after the first mailing. All mailings included the survey web address.

Table 3 summarizes the lower bounds on response rates for contact methods. The response rate only includes respondents who submitted usable responses (over $80 \%$ of basic questions answered) and whose operation included crops (as opposed to livestock only). The actual response rate cannot be determined because some growers were potentially contacted by multiple entities. Growers may have been on both the FDACS and FFB contact lists, and both of these lists contained growers from counties contacted by individual extension agents. Consequently, a single grower may have been contacted through as many as three contact lists, but we did not have access to the FFB or extension lists to identify overlapping growers. As a result, each contact made to the same grower counts as a different grower in the response rate calculations, overestimating the number of growers contacted and inflating the denominator of the calculation. This results in the reported response rate being only a lower bound. 
Table 3

Invitation medium and lower bound on response rates by region or address source.

\begin{tabular}{|c|c|c|c|c|}
\hline Distribution method & Invited & $\begin{array}{l}\text { Started } \\
\text { the survey }\end{array}$ & $\begin{array}{l}\text { Usable } \\
\text { responses }\end{array}$ & $\begin{array}{l}\% \\
\text { usable }\end{array}$ \\
\hline \multicolumn{5}{|l|}{ County extension offices } \\
\hline Bay & 5 & 2 & 1 & 20.00 \\
\hline Duval & 2 & 1 & 0 & 0.00 \\
\hline Manatee & 224 & 7 & 4 & 1.79 \\
\hline Martin & 3 & 3 & 2 & 66.67 \\
\hline Miami-Dade & 30 & 4 & 4 & 13.33 \\
\hline Okaloosa & 9 & 5 & 5 & 55.56 \\
\hline Okeechobee & 22 & 0 & 0 & 0.00 \\
\hline Santa Rosa & 12 & 3 & 3 & 25.00 \\
\hline St. Lucie & 2 & 1 & 0 & 0.00 \\
\hline Seminole & 83 & 7 & 0 & 0.00 \\
\hline Volusia & 83 & 4 & 1 & 1.20 \\
\hline Walton & 12 & 2 & 1 & 8.33 \\
\hline \multicolumn{5}{|c|}{$\begin{array}{l}\text { Hendry, Bradford, Palm Beach, } \\
\text { and Levy }\end{array}$} \\
\hline Subtotal & 738 & 102 & 56 & 7.59 \\
\hline FDACS & 509 & 72 & 63 & 12.38 \\
\hline FFB & 255 & 58 & 46 & 18.04 \\
\hline Total & 1,502 & 232 & 165 & 10.99 \\
\hline
\end{tabular}

Notes: FDACS $=$ Florida Department of Agriculture and Consumer Services. FFB = Florida Farm Bureau.

For our two primary sources of respondents, the FDACS and FFB growers, the lower bound on our response rates were about $12 \%$ and $18 \%$, respectively, which meet or exceed the response rates of several recent producer mail surveys conducted in California, which ranged from $11 \%$ to $13.2 \%$ (An and Butler 2012; Goodhue et al. 2002; Grogan and Goodhue 2012). Only one mail survey of Florida vegetable growers could be found in the literature. A survey of Florida growers, ornamental nursery producers, and golf landscapers obtained an 18\% response rate across all survey categories and a $6 \%$ response rate among the vegetable growers (Munoz-Carpena et al. 2003). Growers' time constraints likely limit response rates. Surveys tend to be lengthy to obtain all pertinent information, but this length increases the grower's time cost of completing the survey. Our survey included 32 questions. The mean completion time was 18 minutes, while the median completion time was 13 minutes, indicating a distribution skewed towards a longer completion time. We suspect that the variation in response rates across counties relates to the relationships between the extension agents and the growers. The higher county-level response rates are for those counties where fewer growers were contacted. The smaller contact lists likely contained only growers with whom the agent had a strong relationship, while the larger contact lists may include growers with whom the extension agent has rarely interacted with in person.

While the lower bound on the response rate is not ideal, the analysis that follows is still relevant for two primary reasons. First, the area farmed under all respondents totaled 52,289 ha $(129,211 \mathrm{ac})$, which is $51.5 \%$ of the total farmed land reported in the USDA's 2012 Census of Agriculture for Florida vegetable growers (USDA NASS 2012). Table 4 displays the number of Florida growers reported by the USDA to have grown a given crop in 2012. We compare this with the number of survey respondents by reported crop, and estimate the percentage of the state's growers of each crop represented by the sample. While considerable variation exists across crops, the average percentage is about $36 \%$, further indicating that our estimated response rate is a conservative lower bound and that the same growers were contacted through multiple means, but counted as different growers.

Second, along most measures, the sample is representative of Florida vegetable growers. Table 5 compares farm size, age, experience, and gender of Florida growers and respondents. In terms of gender and experience, our growers closely match the reported distribution of growers. In terms of age, the respondent distribution contains more growers aged 35 to 65 and fewer growers over the age of 65 , compared to the USDA-reported distribution. Given that the population segment that is overrepresented will likely be farming farther into the future than the underrepresented segment, this bias implies that our results will also hold for longer into the future. If our results were driven by growers who were going to retire soon, that would be much more problematic. Lastly, the respondents contain more large operations and fewer small operations than the state of Florida. While this may prevent our analysis from truly representing small farming operations, our results will apply to the majority of farmed land, which is under production in large farming operations and uses the majority of agricultural water.

We analyze the factors that may influence adoption of drought adaptation measures as well as factors that influence the intensity of adoption, utilizing several models. For all models, the independent variables include farm characteristics such as total hectares, percentage of land that is owned, percentage of land under each source of irrigation water, and dummy variables for crops grown. We hypothesize that economies of scale may influence adoption as seen in previous literature (Green et al. 1996; Dinar et al. 1992; Schuck et al. 2005) and that renting land may decrease the likelihood of adoption (Baumgart-Getz et al. 2012; Soule et al. 2000). Participation in cost share programs may decrease costs of and positively affect adoption. Additionally, crops and sources of irrigation water will affect water needs and water reliability, respectively, which likely influence adoption decisions.

We also asked the growers questions about their experiences and opinions pertaining to their water supplies. We asked the growers about their water supply predictability and hypothesize that growers who reported that their supply was predictable would be less likely to adopt drought adaptation measures than growers who reported it as somewhat or often unpredictable. We also asked growers whether or not they have experienced a drought, and if so, if they experienced crop damages as a result of that drought, hypothesizing that those growers who reported 


\section{Table 4}

Comparison of the total number of Florida growers reported by the USDA Census of Agriculture, and the number of survey respondents who reported growing each crop.

\begin{tabular}{|c|c|c|c|}
\hline \multirow[b]{2}{*}{ Crop* } & \multirow[b]{2}{*}{ USDA } & \multicolumn{2}{|c|}{ Respondents } \\
\hline & & Number & $\begin{array}{l}\text { USDA-reported } \\
\text { growers (\%) }\end{array}$ \\
\hline Beans, snap and green & 507 & 35 & 6.90 \\
\hline Broccoli & 76 & 18 & 23.68 \\
\hline Cabbage, Chinese & 36 & 15 & 41.67 \\
\hline Cabbage, head & 99 & 18 & 18.18 \\
\hline Cantaloupes and muskmelons & 202 & 17 & 8.42 \\
\hline Carrots & 37 & 26 & 70.27 \\
\hline Cauliflower & 23 & 8 & 34.78 \\
\hline Celery & 5 & 3 & 60.00 \\
\hline Escarole, endive & 3 & 2 & 66.67 \\
\hline Kale & 45 & 20 & 44.44 \\
\hline Onions, green & 36 & 3 & 8.33 \\
\hline Peas, all & 448 & 23 & 5.13 \\
\hline Peppers, bell & 122 & 46 & 37.70 \\
\hline Peppers, not bell & 80 & 29 & 36.25 \\
\hline Potatoes & 322 & 23 & 7.14 \\
\hline Pumpkins & 30 & 11 & 36.67 \\
\hline Radishes & 27 & 24 & 88.89 \\
\hline Spinach $†$ & 10 & 20 & 100.00 \\
\hline Squash, summer & 194 & 29 & 14.95 \\
\hline Sweet corn & 451 & 28 & 6.21 \\
\hline Tomatoes, not greenhouse & 565 & 53 & 9.38 \\
\hline Turnips & 17 & 16 & 94.12 \\
\hline Watermelons & 430 & 26 & 6.05 \\
\hline Average & & & 35.91 \\
\hline \multicolumn{4}{|c|}{$\begin{array}{l}\text { *Crops reported are those crops for which the definition used and reported by the Census of } \\
\text { Agriculture matched the crop categories used in the survey. }\end{array}$} \\
\hline $\begin{array}{l}\text { †The USDA reports } 10 \text { spinach } \\
\text { This discrepancy may result fro } \\
\text { nonresponse (USDA NASS } 201\end{array}$ & $\begin{array}{l}\text { while } 2 \\
\text { putation }\end{array}$ & esponden & $\begin{array}{l}\text { d growing spinach. } \\
\text { to account for }\end{array}$ \\
\hline
\end{tabular}

both drought and drought-induced damage would be more likely to adopt drought adaptation measures. Additionally, we asked growers if they foresaw future water problems, and hypothesize that growers who believed future water availability would sometimes be or often be problematic would be more likely to adopt measures. Finally, we asked the growers about how they perceived their neighbors' beliefs about water conservation and drought adaptation in case a neighbor's positive beliefs increases the respondent's likelihood of adoption. Additionally, we include grower characteristics such as age, gender, and highest level of education completed and hypothesize that adoption will be positively correlated with education (Koundouri et al. 2006; Schuck et al. 2005) and negatively correlated with age (He et al. 2007). Since some growers did not respond to all demographic questions, we entered the mean respondent values for respondents who failed to report their gender, age, or education status. This affected less than $10 \%$ of the observations. For each individual adaptation measure, we estimate a probit model of adoption. Since the choice to adopt a given measure may be influenced by similar unobserved factors that influence the adoption of other measures, we also estimated multivariate probit models to test for correlation of the error terms across equations. However, we could not reject the null hypothesis of independence across equations, so we do not report these results.

We define intensity of adoption as the number of measures adopted within a drought adaptation category. We consider three models for each of the three categories of adaptations. For each category, observa- tions are censored at zero and the maximum possible number of adaptations in that category. For each category, there are sizable probability masses at one or both endpoints, suggesting that the tobit model is appropriate. We also estimate ordered probit models for intensity of adoption of each class since the choice of the number of measures to adopt could be considered as a ranked variable. Lastly, we estimate one seemingly unrelated regression (SUR) model that includes one equation for each category since there may be unobservable characteristics that affect intensity of adoption across categories.

\section{Results and Discussion}

Table 6 provides summary statistics of the independent and dependent variables, and table 7 provides adoption rates for each crop family and region of Florida. Adoption of augmentation measures is relatively low. About 15\% of respondents harvest rainwater while $13 \%$ recover tailwater. The average respondent utilized neither measure. Respondents in Central Florida have the highest adoption rates of both augmentation measures. Strawberry (Fragaria ananassa) producers have the highest adoption rate of tailwater recovery, while ornamental producers have the highest adoption rate of rainwater harvesting.

Adoption of loss reduction measures was higher on average, although more variable across measures. About $51 \%$ of respondents have adopted micro-irrigation on at least a portion of their land. About 25\% and 23\% have leveled their land or applied mulch, respectively, while about $21 \%$ use alternative freeze protection. The average respondent has adopted 1.2 loss reduction measures. The relatively higher adoption of loss reduction measures may explain the lower adoption of tailwater recovery; when less water is lost in the irrigation process, the benefit of tailwater recovery is reduced.

At the regional level, respondents in Central Florida have the highest adoption rates of micro-irrigation and mulch, while respondents in South Florida have the highest adoption rates of land leveling and alternative freeze protection. Growers in South Florida face milder and less frequent freezes, potentially allowing them more flexibility in freeze protection methods. At the crop level, strawberry growers have the highest adoption rates of mulch and alternative freeze protection, tree crop growers have the 
Table 5

Distribution of grower characteristics as reported by the USDA Census of Agriculture and for respondents.

\begin{tabular}{|c|c|c|}
\hline Characteristic & $\begin{array}{l}\text { All Florida farms/growers } \\
(\%)\end{array}$ & Respondents (\%) \\
\hline Female & 20.9 & 20.3 \\
\hline \multicolumn{3}{|l|}{ Experience (years) } \\
\hline$<2$ & 3.4 & 5.0 \\
\hline 3 to 4 & 5.4 & 7.9 \\
\hline 5 to 9 & 17.1 & 15.8 \\
\hline $10+$ & 74.0 & 71.3 \\
\hline \multicolumn{3}{|l|}{ Age (years) } \\
\hline$<25$ & 1.3 & 1.9 \\
\hline 25 to 34 & 4.5 & 5.8 \\
\hline 35 to 44 & 10.4 & 11.5 \\
\hline 45 to 54 & 23.9 & 31.7 \\
\hline 55 to 64 & 28.1 & 38.5 \\
\hline 65 to 74 & 21.1 & 8.7 \\
\hline 75 and over & 10.6 & 1.9 \\
\hline \multicolumn{3}{|l|}{ Total crop hectares } \\
\hline 0.04 to 0.36 & 19.1 & 2.8 \\
\hline 0.4 to 1.9 & 34.6 & 11.9 \\
\hline 2.0 to 6.0 & 17.2 & 12.6 \\
\hline 6.07 to 10.07 & 4.4 & 4.2 \\
\hline 10.1 to 19.8 & 4.8 & 6.3 \\
\hline 20.2 to 40.4 & 4.5 & 9.1 \\
\hline 40.45 to 101.1 & 4.6 & 14.0 \\
\hline 101.2 to 202.3 & 2.9 & 12.6 \\
\hline 202.34 to 303.4 & 2.4 & 2.1 \\
\hline 303.5 to 404.6 & 1.5 & 2.8 \\
\hline 404.7 to 809.3 & 2.6 & 7.7 \\
\hline 809.4 to $1,214.0$ & 0.6 & 9.8 \\
\hline $1,14.1$ to $2,023.3$ & 0.4 & 0.7 \\
\hline 2,023.4 and over & 0.5 & 4.9 \\
\hline
\end{tabular}

highest adoption rate of micro-irrigation, and producers of nightshades (Solanaceae) have the highest adoption rate of land leveling. This latter result is likely influenced by the high rate of gravity irrigation systems utilized by potato growers; uneven land would create an uneven distribution of water.

In terms of irrigation planning, variable rate and scheduled irrigation had the highest adoption rate with about $55 \%$ of respondents reporting its use. Automatic systems and weather stations have been adopted by $45 \%$ and $34 \%$ of respondents, respectively, while soil moisture sensors have only been adopted by $26 \%$. The relatively high cost per hectare for soil moisture sensors may explain the lower rate of adoption for sensors. On average, respondents have adopted 1.55 irrigation planning measures.
At the regional level, respondents in Central Florida had the highest adoption rates of soil moisture sensors, variable rate irrigation, and automatic irrigation systems, while South Florida respondents had the highest adoption rate of weather stations. At the crop level, strawberry growers had the highest adoption rates of soil moisture sensors and variable rate irrigation, respondents growing crops in the onion (Allium сера) family had the highest adoption rate of weather stations, and finally, respondents who grew crops in the goosefoot (Chenopodium album L.) family had the highest adoption rate of automatic irrigation systems.

Out of all 10 adaptation measures, respondents have adopted about 3 measures on average. Central Florida growers have the highest average adoption rates across measures, followed by South Florida growers.
Producers of strawberries and crops in the nightshade, cucurbit (Cucurbitaceae), and goosefoot families have the highest average adoption rates across measures, while producers of crops in the grass, ornamental, and legume families have the lowest average adoption rates.

Adoption of Individual Augmentation Measures. The first models we estimated were probit models of adoption of individual augmentation measures - tailwater recovery and rainwater harvesting (table 8). We find that as land area increases, the probability of adopting tailwater recovery and rainwater harvesting increases. Since tailwater recovery involves an investment in infrastructure, it is not surprising that rates of adoption increase as area increases. Rainwater harvesting has a smaller investment, but larger farms likely also have more rooftop surface areas from which to harvest rain. Growers with a higher percentage of hectares owned as opposed to rented are more likely to adopt tailwater recovery. This is likely driven by the infrastructure investment required by tailwater recovery, and the uncertainty of continued rental land use. Both of these trends are consistent with previous work (Baumgart-Getz et al. 2012; Green et al. 1996; Dinar et al. 1992; Schuck et al. 2005; Soule et al. 2000).

Several drought experience and perception variables determine adoption, although not all in predictable ways. No respondent who thought that his water supply was unpredictable adopted tailwater recovery so that variable could not be included in the model. Those who experienced drought with crop damage in the past are more likely to adopt rainwater harvesting, and those who foresee future water supply problems are more likely to adopt tailwater recovery and rainwater harvesting. Finally, those whose neighbors view water conservation positively are more likely to adopt tailwater recovery.

In terms of grower characteristics, age is the only statistically significant predictor of adoption; older growers are less likely to adopt tailwater recovery than younger growers. This could be due to the shorter time horizon for which growers will use the recovery infrastructure, making the investment less beneficial. Previous work found that older growers were less likely to adopt rainwater harvesting (He et al. 2007), but we found no relationship between age and adoption of rainwater harvesting. 


\section{Table 6}

Summary statistics of drought adaptation adoption, farm characteristics, drought perceptions, and grower characteristics.

\begin{tabular}{|c|c|c|c|c|}
\hline Characteristic & $\begin{array}{l}\text { Number } \\
\text { observed }\end{array}$ & Mean & Min & Max \\
\hline \multicolumn{5}{|l|}{ Augmentation measures } \\
\hline Tailwater & 137 & 0.131 & 0 & 1 \\
\hline Rainwater & 137 & 0.153 & 0 & 1 \\
\hline Total used & 137 & 0.285 & 0 & 2 \\
\hline \multicolumn{5}{|l|}{ Loss reduction measures } \\
\hline Micro-irrigation & 146 & 0.514 & 0 & 1 \\
\hline Mulch & 137 & 0.226 & 0 & 1 \\
\hline Leveling & 137 & 0.248 & 0 & 1 \\
\hline Alternative freeze protection & 137 & 0.212 & 0 & 1 \\
\hline Total used & 137 & 1.197 & 0 & 4 \\
\hline \multicolumn{5}{|l|}{ Irrigation measures } \\
\hline Sensors & 126 & 0.262 & 0 & 1 \\
\hline Variable rates & 126 & 0.548 & 0 & 1 \\
\hline Weather station & 126 & 0.341 & 0 & 1 \\
\hline Automatic system & 124 & 0.452 & 0 & 1 \\
\hline Total & 123 & 1.553 & 0 & 4 \\
\hline All measures & 113 & 3.194 & 0 & 9 \\
\hline Total hectares & 143 & 890.070 & 0.1 & 16,000 \\
\hline Hectares owned (\%) & 143 & 0.745 & 0 & 1 \\
\hline \multicolumn{5}{|l|}{ Crop families } \\
\hline Nightshade & 155 & 0.439 & 0 & 1 \\
\hline Cucurbits & 155 & 0.303 & 0 & 1 \\
\hline Goosefoot & 155 & 0.135 & 0 & 1 \\
\hline Sunflower & 155 & 0.187 & 0 & 1 \\
\hline Brassicas & 155 & 0.271 & 0 & 1 \\
\hline Onions & 155 & 0.181 & 0 & 1 \\
\hline Legumes & 155 & 0.329 & 0 & 1 \\
\hline Parsley & 155 & 0.181 & 0 & 1 \\
\hline Ornamental & 155 & 0.142 & 0 & 1 \\
\hline Strawberries & 155 & 0.123 & 0 & 1 \\
\hline Tree crops & 155 & 0.155 & 0 & 1 \\
\hline Grasses & 155 & 0.348 & 0 & 1 \\
\hline Other & 155 & 0.058 & 0 & 1 \\
\hline Water supply predictable & 133 & 0.669 & 0 & 1 \\
\hline Experienced drought with damage & 143 & 0.217 & 0 & 1 \\
\hline Foresee future water problems & 143 & 0.594 & 0 & 1 \\
\hline Positive neighbor & 130 & 0.308 & 0 & 1 \\
\hline Cost share program & 132 & 0.258 & 0 & 1 \\
\hline \multicolumn{5}{|l|}{ Area using irrigation water source (\%) } \\
\hline Surface & 132 & 65.583 & 0 & 100 \\
\hline Groundwater & 132 & 17.045 & 0 & 100 \\
\hline Collected rain water & 132 & 1.500 & 0 & 60 \\
\hline Female & 118 & 0.203 & 0 & 1 \\
\hline College degree & 117 & 0.607 & 0 & 1 \\
\hline Age & 98 & 52.490 & 22 & 79 \\
\hline
\end{tabular}

Adoption of Individual Water Loss Reduction Measures. For the adoption of individual loss reduction measures, some trends from the augmentation measures persist, while others differ (table 9). In terms of farm characteristics, larger area is associated with increased adoption of mulching, but has no effect on the other measures. Unlike results found in previous work (BaumgartGetz et al.2012; Soule et al.2000), percentage of hectares owned is negatively correlated with adoption of mulch, land leveling, and alternative freeze protection, although the magnitude of the marginal effect is small. With respect to mulch, this is not surprising since mulch does not require a large infrastructure investment that would be lost when the lease ends. However, investments associated with land leveling would be lost when the lease ends. Landowners may be more likely to lease out uneven land, making leveling more necessary on leased land. Lastly, with respect to alternative freeze protection measures, many of the alternatives are mobile, so such investments will not be lost when the lease ends.

Among the drought experience and perceptions variables, only two are significant. Growers who report an unpredictable water supply are about 36\% less likely to adopt micro-irrigation than other growers. Growers may perceive a more unpredictable water supply if they have larger water needs due to the use of less efficient irrigation systems and experience damage from variations in water supply. Additionally, growers whose neighbors have positive opinions of water conservation are about 17\% more likely to adopt mulch than growers whose neighbors have neutral or negative opinions.

All three grower characteristics are statistically significant in at least one model. Females are about $84 \%$ more likely to adopt mulch than males. Growers with at least a college degree are more likely to adopt mulch, land leveling, and alternative freeze protection than growers without a college degree, coinciding with previous literature (Knowler and Bradshaw). While older growers are less likely to adopt tailwater recovery, they are more likely to adopt mulch than younger growers, with a $6.5 \%$ increase in probability for every year of age.

Adoption of Individual Irrigation Planning Measures. The results for irrigation planning measures differ substantially from the previous two categories (table 10). Total land 
Table 7

Adoption rates by crop family and region.

\begin{tabular}{|c|c|c|c|c|c|c|c|c|c|c|c|}
\hline \multirow[b]{2}{*}{ Family/region } & \multirow[b]{2}{*}{$\begin{array}{l}\text { Number of } \\
\text { respondents }\end{array}$} & \multicolumn{2}{|c|}{ Augmentation (\%) } & \multicolumn{4}{|c|}{ Loss reduction (\%) } & \multicolumn{4}{|c|}{ Irrigation (\%) } \\
\hline & & $\begin{array}{l}\text { Tailwater } \\
\text { recovery }\end{array}$ & $\begin{array}{l}\text { Rainwater } \\
\text { harvest }\end{array}$ & $\begin{array}{l}\text { Micro- } \\
\text { irrigation }\end{array}$ & Mulch & $\begin{array}{l}\text { Land } \\
\text { level }\end{array}$ & $\begin{array}{l}\text { Alternative } \\
\text { freeze } \\
\text { protection }\end{array}$ & $\begin{array}{l}\text { Soil } \\
\text { sensors }\end{array}$ & $\begin{array}{l}\text { Variable } \\
\text { irrigation } \\
\text { rates }\end{array}$ & $\begin{array}{l}\text { Weather } \\
\text { station }\end{array}$ & $\begin{array}{l}\text { Automatic } \\
\text { irrigation }\end{array}$ \\
\hline \multicolumn{12}{|l|}{ Crop family } \\
\hline Nightshade & 61 & 15.79 & 24.56 & 65.57 & 37.93 & 32.76 & 29.31 & 24.07 & 51.85 & 35.19 & 47.17 \\
\hline Cucurbits & 43 & 17.50 & 10.00 & 72.09 & 39.53 & 25.58 & 23.26 & 27.50 & 61.54 & 33.33 & 48.72 \\
\hline Brassicas & 38 & 11.76 & 26.47 & 63.16 & 32.43 & 13.51 & 10.81 & 12.12 & 45.45 & 36.36 & 60.61 \\
\hline Onions & 25 & 8.70 & 26.09 & 64.00 & 32.00 & 16.00 & 12.00 & 14.29 & 52.38 & 47.62 & 61.90 \\
\hline Legumes & 49 & 8.70 & 17.39 & 55.10 & 27.08 & 18.75 & 18.75 & 19.57 & 52.27 & 28.89 & 45.45 \\
\hline Parsley & 26 & 4.17 & 25.00 & 65.38 & 38.46 & 19.23 & 19.23 & 12.50 & 41.67 & 37.50 & 62.50 \\
\hline Ornamental & 20 & 10.53 & 42.11 & 40.00 & 21.05 & 10.53 & 5.26 & 6.67 & 47.06 & 35.29 & 56.25 \\
\hline Strawberries & 17 & 31.25 & 25.00 & 70.59 & 52.94 & 29.41 & 29.41 & 28.57 & 64.29 & 42.86 & 57.14 \\
\hline North & 42 & 8.11 & 2.70 & 28.57 & 12.82 & 12.82 & 12.82 & 30.56 & 42.42 & 17.65 & 18.18 \\
\hline Central & 18 & 38.89 & 27.78 & 61.11 & 35.29 & 41.18 & 29.41 & 35.71 & 73.33 & 28.57 & 71.43 \\
\hline South & 18 & 5.88 & 11.76 & 50.00 & 27.78 & 72.22 & 61.11 & 11.11 & 61.11 & 33.33 & 27.78 \\
\hline
\end{tabular}

\section{Table 8}

The probability of adopting individual augmentation measures, coefficients, and marginal effects from probit models, $n=110$.

\begin{tabular}{|c|c|c|c|c|}
\hline \multirow[b]{2}{*}{ Characteristic } & \multicolumn{2}{|l|}{ Tailwater } & \multicolumn{2}{|l|}{ Rainwater } \\
\hline & Coefficient & Marginal & Coefficient & Marginal \\
\hline Total hectares (1,000s) & $\begin{array}{l}0.5691 * \\
(0.3410)\end{array}$ & $\begin{array}{c}0.0085 \\
(0.0095)\end{array}$ & $\begin{array}{l}0.4876 * * \\
(0.2009)\end{array}$ & $\begin{array}{c}0.0023 \\
(0.0021)\end{array}$ \\
\hline Percentage of hectares owned (\%) & $\begin{array}{l}1.6499 * * \\
(0.0008)\end{array}$ & $\begin{array}{c}0.0246 \\
(0.0261)\end{array}$ & $\begin{array}{c}-0.8512 \\
(0.7175)\end{array}$ & $\begin{array}{r}-0.0040 \\
(0.0038)\end{array}$ \\
\hline Water supply unpredictable & & & $\begin{array}{c}0.8726 \\
(0.8201)\end{array}$ & $\begin{array}{c}0.0125 \\
(0.0276)\end{array}$ \\
\hline Experienced drought with damage & $\begin{array}{c}-0.0582 \\
(0.5663)\end{array}$ & $\begin{array}{c}-0.0008 \\
(0.0077)\end{array}$ & $\begin{array}{l}2.2601 * * * \\
(0.7177)\end{array}$ & $\begin{array}{c}0.1162 \\
(0.0877)\end{array}$ \\
\hline Foresee future water problems & $\begin{array}{l}1.1407 \text { ** } \\
(0.4947)\end{array}$ & $\begin{array}{c}0.0153 \\
(0.0132)\end{array}$ & $\begin{array}{l}-2.2058 * * * \\
(0.5188)\end{array}$ & $\begin{array}{c}-0.0621 \\
(0.0388)\end{array}$ \\
\hline Positive neighbor & $\begin{array}{l}0.8223^{*} \\
(0.4417)\end{array}$ & $\begin{array}{c}0.0196 \\
(0.0224)\end{array}$ & $\begin{array}{c}-0.6871 \\
(0.6541)\end{array}$ & $\begin{array}{r}-0.0025 \\
(0.0023)\end{array}$ \\
\hline Cost share program & $\begin{array}{c}0.4148 \\
(0.4108)\end{array}$ & $\begin{array}{c}0.0079 \\
(0.0119)\end{array}$ & $\begin{array}{c}0.4967 \\
(0.5627)\end{array}$ & $\begin{array}{r}0.0036 \\
(0.0071)\end{array}$ \\
\hline Female & $\begin{array}{c}-0.8579 \\
(0.7069)\end{array}$ & $\begin{array}{c}-0.0072 \\
(0.0075)\end{array}$ & $\begin{array}{c}-0.1732 \\
(0.5881)\end{array}$ & $\begin{array}{c}-0.0007 \\
(0.0019)\end{array}$ \\
\hline College degree & $\begin{array}{c}-0.5201 \\
(0.4244)\end{array}$ & $\begin{array}{r}-0.0103 \\
(0.0145)\end{array}$ & $\begin{array}{c}-0.3427 \\
(0.5902)\end{array}$ & $\begin{array}{r}-0.0020 \\
(0.0044)\end{array}$ \\
\hline Age & $\begin{array}{l}-0.0539 * * \\
(0.0231)\end{array}$ & $\begin{array}{c}-0.0008 \\
(0.0008)\end{array}$ & $\begin{array}{c}0.0461 \\
(0.0327)\end{array}$ & $\begin{array}{c}0.0002 \\
(0.0002)\end{array}$ \\
\hline Constant & $\begin{array}{c}-2.6246 \\
(1.6652)\end{array}$ & & $\begin{array}{c}-4.3951 * \\
(2.3499)\end{array}$ & \\
\hline Controls for crops grown and water source & Yes & & Yes & \\
\hline pseudo $r^{2}$ & 0.454 & & 0.400 & \\
\hline
\end{tabular}


Table 9

The probability of adoption of individual loss reduction measures, coefficients, and marginal effects, $n=124$.

\begin{tabular}{|c|c|c|c|c|c|c|c|c|}
\hline \multirow[b]{2}{*}{ Characteristic } & \multicolumn{2}{|l|}{ Mulch } & \multicolumn{2}{|l|}{ Land leveling } & \multicolumn{2}{|c|}{$\begin{array}{l}\text { Alternative freeze } \\
\text { protection }\end{array}$} & \multicolumn{2}{|c|}{ Micro-irrigation } \\
\hline & Coefficient & Marginal & Coefficient & Marginal & Coefficient & Marginal & Coefficient & Marginal \\
\hline Total hectares $(1,000 \mathrm{~s})$ & $\begin{array}{l}0.8833 * * * \\
(0.3070)\end{array}$ & $\begin{array}{l}0.1417 * * \\
(0.0584)\end{array}$ & $\begin{array}{c}0.2177 \\
(0.2187)\end{array}$ & $\begin{array}{c}0.0349 \\
(0.0382)\end{array}$ & $\begin{array}{c}0.2548 \\
(0.2242)\end{array}$ & $\begin{array}{c}0.0308 \\
(0.0302)\end{array}$ & $\begin{array}{c}0.1887 \\
(0.1759)\end{array}$ & $\begin{array}{c}0.0751 \\
(0.0700)\end{array}$ \\
\hline Percentage hectares owned & $\begin{array}{l}-1.2807 * * \\
(0.5136)\end{array}$ & $\begin{array}{l}-0.2055 * * \\
(0.0864)\end{array}$ & $\begin{array}{l}-0.9801^{*} \\
(0.5834)\end{array}$ & $\begin{array}{l}-0.1573^{*} \\
(0.0937)\end{array}$ & $\begin{array}{l}-1.2975 * * \\
(0.5508)\end{array}$ & $\begin{array}{l}-0.1571 * * \\
(0.0697)\end{array}$ & $\begin{array}{l}-0.1616 \\
(0.4475)\end{array}$ & $\begin{array}{c}-0.0643 \\
(0.1780)\end{array}$ \\
\hline $\begin{array}{l}\text { Experienced drought } \\
\text { damage }\end{array}$ & $\begin{array}{c}0.0943 \\
(0.4666)\end{array}$ & $\begin{array}{c}0.0157 \\
(0.0793)\end{array}$ & $\begin{array}{c}0.1080 \\
(0.4335)\end{array}$ & $\begin{array}{c}0.0180 \\
(0.0757)\end{array}$ & $\begin{array}{l}-0.0674 \\
(0.4721)\end{array}$ & $\begin{array}{l}-0.0079 \\
(0.0539)\end{array}$ & $\begin{array}{c}0.4972 \\
(0.3873)\end{array}$ & $\begin{array}{c}0.1922 \\
(0.1436)\end{array}$ \\
\hline $\begin{array}{l}\text { Foresee future water } \\
\text { problems }\end{array}$ & $\begin{array}{l}-0.5379 \\
(0.4501)\end{array}$ & $\begin{array}{l}-0.0963 \\
(0.0854)\end{array}$ & $\begin{array}{c}0.1117 \\
(0.4624)\end{array}$ & $\begin{array}{c}0.0175 \\
(0.0716)\end{array}$ & $\begin{array}{c}0.1697 \\
(0.4249)\end{array}$ & $\begin{array}{c}0.0198 \\
(0.0477)\end{array}$ & $\begin{array}{c}0.1791 \\
(0.3243)\end{array}$ & $\begin{array}{c}0.0713 \\
(0.1288)\end{array}$ \\
\hline Positive neighbor & $\begin{array}{l}0.8564 * * \\
(0.4234)\end{array}$ & $\begin{array}{l}0.1728^{*} \\
(0.0918)\end{array}$ & $\begin{array}{l}-0.1077 \\
(0.3828)\end{array}$ & $\begin{array}{l}-0.0168 \\
(0.0594)\end{array}$ & $\begin{array}{c}0.3747 \\
(0.3767)\end{array}$ & $\begin{array}{c}0.0512 \\
(0.0573)\end{array}$ & $\begin{array}{l}-0.1484 \\
(0.3123)\end{array}$ & $\begin{array}{l}-0.0591 \\
(0.1243)\end{array}$ \\
\hline Female & $\begin{array}{l}0.8353^{*} \\
(0.4783)\end{array}$ & $\begin{array}{c}0.1842 \\
(0.1277)\end{array}$ & $\begin{array}{c}-0.2511 \\
(0.4773)\end{array}$ & $\begin{array}{c}-0.0363 \\
(0.0611)\end{array}$ & $\begin{array}{c}-0.2961 \\
(0.5139)\end{array}$ & $\begin{array}{c}-0.0312 \\
(0.0447)\end{array}$ & $\begin{array}{c}0.2908 \\
(0.3368)\end{array}$ & $\begin{array}{c}0.1141 \\
(0.1296)\end{array}$ \\
\hline College degree & $\begin{array}{l}0.7246 * \\
(0.4001)\end{array}$ & $\begin{array}{l}0.1035 * * \\
(0.0481)\end{array}$ & $\begin{array}{c}0.7016 \\
(0.4702)\end{array}$ & $\begin{array}{l}0.1006 * * \\
(0.0511)\end{array}$ & $\begin{array}{l}0.8139 * \\
(0.4793)\end{array}$ & $\begin{array}{l}0.0863 * * \\
(0.0389)\end{array}$ & $\begin{array}{l}0.0418 \\
(0.3028)\end{array}$ & $\begin{array}{l}0.0166 \\
(0.1205)\end{array}$ \\
\hline Age & $\begin{array}{l}0.0405 * * \\
(0.0201)\end{array}$ & $\begin{array}{l}0.0065 * * \\
(0.0032)\end{array}$ & $\begin{array}{c}0.0287 \\
(0.0199)\end{array}$ & $\begin{array}{c}0.0046 \\
(0.0033)\end{array}$ & $\begin{array}{c}0.0288 \\
(0.0215)\end{array}$ & $\begin{array}{c}0.0035 \\
(0.0027)\end{array}$ & $\begin{array}{l}-0.0052 \\
(0.0141)\end{array}$ & $\begin{array}{l}-0.0021 \\
(0.0056)\end{array}$ \\
\hline Constant & $\begin{array}{l}-4.5543 * * * \\
(1.3352)\end{array}$ & & $\begin{array}{l}-5.2264 * * * \\
(1.4936)\end{array}$ & & $\begin{array}{l}-5.0611 * * * \\
(1.5559)\end{array}$ & & $\begin{array}{l}-1.2625 \\
(0.9581)\end{array}$ & \\
\hline $\begin{array}{l}\text { Controls for crops grown } \\
\text { and water source }\end{array}$ & Yes & & Yes & & Yes & & Yes & \\
\hline
\end{tabular}

area is insignificant for all measures. The percentage of land owned is positively correlated with weather station use. Among the drought experience and perceptions variables, growers who foresee future water problems are about $20 \%$ more likely to adopt weather stations than other growers. Interestingly, growers with neighbors with positive opinions on water conservation are about $28 \%$ less likely to adopt variable irrigation. They may see less of a need to vary their irrigation rates or timing if their neighbors are actively conserving water.

Unlike the previous models, participation in cost shares is significant for soil moisture sensor adoption. Growers who participate in these programs (primarily EQIP and the FDACS BMP program) are almost 38\% more likely to adopt sensors than nonparticipants. Neither cost share program is specific to soil moisture sensors, although they could be part of an irrigation efficiency improvement that would qualify for either program. Implementation of sensors is potentially a large investment; cost share programs eliminate the majority of this investment cost.

Among grower characteristics, two variables are significant. First, female growers are about $43 \%$ and $22 \%$ less likely to adopt variable irrigation and weather stations, respectively, than male growers. Second, growers with a college degree are about $27 \%$ more likely to use variable irrigation, consistent with previous work (Koundouri et al. 2006; Schuck et al. 2005; He et al. 2007; Dorfman 1996). Such growers may have more ability or inclination to adjust rates and timing.

Intensity of Adoption. Our last set of models determine the factors that affect the intensity of adoption of the three categories of measures - that is to say, which factors affect how many measures within each category the grower adopts. For the SUR model, intensity of adoption of augmentation, loss reduction, and irrigation planning measures are estimated in the same SUR model, but displayed in table 11 separately under the adoption category heading for comparison purposes. The results are largely robust across the three specifications, but the effects of variables differ across adaptation categories.

The total number of hectares positively affects intensity of adoption of both augmentation and loss reduction measures. The percentage of hectares that is owned and an unpredictable water supply are negatively correlated with intensity of adoption of loss reduction measures. At the same time, growers who perceive future water problems have higher intensity of adoption of irrigation measures. Cost share programs have positive effects on the intensity of adoption of both augmentation measures and irrigation measures, suggesting that cost share programs are effectively encouraging adoption of some drought adaptation and water conservation measures.

Among demographic variables, females have lower intensity of adoption of augmentation and irrigation measures, but higher intensity of adoption of loss reduction measures than males. This is an interesting finding, and highlights the importance of consider- 
Table 10

The probability of adoption of individual irrigation planning measures, coefficients, and marginal effects, $n=119$.

\begin{tabular}{|c|c|c|c|c|c|c|c|c|}
\hline \multirow[b]{2}{*}{ Characteristic } & \multicolumn{2}{|c|}{ Moisture sensors } & \multicolumn{2}{|c|}{ Variable irrigation } & \multicolumn{2}{|c|}{ Weather station } & \multicolumn{2}{|c|}{ Automatic irrigation } \\
\hline & Coefficient & Marginal & Coefficient & Marginal & Coefficient & Marginal & Coefficient & Marginal \\
\hline Total hectares $(1,000 \mathrm{~s})$ & $\begin{array}{l}-0.0617 \\
(0.1561)\end{array}$ & $\begin{array}{l}-0.0160 \\
(0.0403)\end{array}$ & $\begin{array}{c}0.0068 \\
(0.1944)\end{array}$ & $\begin{array}{c}0.0027 \\
(0.0771)\end{array}$ & $\begin{array}{c}0.1859 \\
(0.1506)\end{array}$ & $\begin{array}{c}0.0401 \\
(0.0320)\end{array}$ & $\begin{array}{c}0.0913 \\
(0.1373)\end{array}$ & $\begin{array}{c}0.0357 \\
(0.0537)\end{array}$ \\
\hline Percentage hectares owned & $\begin{array}{l}-0.0376 \\
(0.4446)\end{array}$ & $\begin{array}{l}-0.0097 \\
(0.1152)\end{array}$ & $\begin{array}{l}-0.5241 \\
(0.4508)\end{array}$ & $\begin{array}{l}-0.2078 \\
(0.1786)\end{array}$ & $\begin{array}{c}0.9116^{*} \\
(0.4881)\end{array}$ & $\begin{array}{l}0.1967^{*} \\
(0.1098)\end{array}$ & $\begin{array}{c}0.2802 \\
(0.4484)\end{array}$ & $\begin{array}{c}0.1096 \\
(0.1752)\end{array}$ \\
\hline Water supply unpredictable & $\begin{array}{r}-0.2678 \\
(0.5376)\end{array}$ & $\begin{array}{c}-0.0622 \\
(0.1106)\end{array}$ & $\begin{array}{l}0.0913 \\
(0.5295)\end{array}$ & $\begin{array}{c}0.0360 \\
(0.2076)\end{array}$ & $\begin{array}{l}-0.4305 \\
(0.7321)\end{array}$ & $\begin{array}{l}-0.0757 \\
(0.0980)\end{array}$ & $\begin{array}{l}-0.1914 \\
(0.5069)\end{array}$ & $\begin{array}{l}-0.0735 \\
(0.1902)\end{array}$ \\
\hline $\begin{array}{l}\text { Experienced drought with } \\
\text { damage }\end{array}$ & $\begin{array}{c}0.1449 \\
(0.4419)\end{array}$ & $\begin{array}{c}0.0389 \\
(0.1225)\end{array}$ & $\begin{array}{l}0.1943 \\
(0.4455)\end{array}$ & $\begin{array}{c}0.0764 \\
(0.1731)\end{array}$ & $\begin{array}{l}-0.1983 \\
(0.4655)\end{array}$ & $\begin{array}{l}-0.0403 \\
(0.0896)\end{array}$ & $\begin{array}{r}-0.6405 \\
(0.4173)\end{array}$ & $\begin{array}{c}-0.2358 * \\
(0.1397)\end{array}$ \\
\hline $\begin{array}{l}\text { Foresee future water } \\
\text { problems }\end{array}$ & $\begin{array}{c}0.3258 \\
(0.3369)\end{array}$ & $\begin{array}{c}0.0803 \\
(0.0789)\end{array}$ & $\begin{array}{l}-0.3825 \\
(0.3215)\end{array}$ & $\begin{array}{l}-0.1494 \\
(0.1225)\end{array}$ & $\begin{array}{l}1.1429 * * * \\
(0.3689)\end{array}$ & $\begin{array}{l}0.2034 * * * \\
(0.0597)\end{array}$ & $\begin{array}{c}0.4187 \\
(0.3309)\end{array}$ & $\begin{array}{c}0.1602 \\
(0.1222)\end{array}$ \\
\hline Positive neighbor & $\begin{array}{l}-0.1161 \\
(0.3206)\end{array}$ & $\begin{array}{l}-0.0294 \\
(0.0800)\end{array}$ & $\begin{array}{l}-0.7093 * * \\
(0.3551)\end{array}$ & $\begin{array}{l}-0.2771 * * \\
(0.1326)\end{array}$ & $\begin{array}{l}-0.0397 \\
(0.3448)\end{array}$ & $\begin{array}{l}-0.0085 \\
(0.0732)\end{array}$ & $\begin{array}{c}0.2052 \\
(0.3219)\end{array}$ & $\begin{array}{c}0.0807 \\
(0.1268)\end{array}$ \\
\hline College degree & $\begin{array}{c}0.2433 \\
(0.3049)\end{array}$ & $\begin{array}{c}0.0607 \\
(0.0732)\end{array}$ & $\begin{array}{l}0.6921 * * \\
(0.3200)\end{array}$ & $\begin{array}{l}0.2707 * * \\
(0.1202)\end{array}$ & $\begin{array}{l}-0.0209 \\
(0.3350)\end{array}$ & $\begin{array}{l}-0.0045 \\
(0.0728)\end{array}$ & $\begin{array}{c}0.3752 \\
(0.2991)\end{array}$ & $\begin{array}{c}0.1441 \\
(0.1119)\end{array}$ \\
\hline Age & $\begin{array}{l}-0.0121 \\
(0.0184)\end{array}$ & $\begin{array}{l}-0.0031 \\
(0.0048)\end{array}$ & $\begin{array}{c}0.0244 \\
(0.0149)\end{array}$ & $\begin{array}{c}0.0097 \\
(0.0059)\end{array}$ & $\begin{array}{l}-0.0247 \\
(0.0160)\end{array}$ & $\begin{array}{l}-0.0053 \\
(0.0034)\end{array}$ & $\begin{array}{c}0.0066 \\
(0.0168)\end{array}$ & $\begin{array}{c}0.0026 \\
(0.0066)\end{array}$ \\
\hline Constant & $\begin{array}{l}-0.0645 \\
(1.1120)\end{array}$ & & $\begin{array}{l}-2.3733 * * \\
(0.9542)\end{array}$ & & $\begin{array}{l}-0.9296 \\
(1.0306)\end{array}$ & & $\begin{array}{l}-2.1114 * * \\
(1.0649)\end{array}$ & \\
\hline $\begin{array}{l}\text { Controls for crops grown and } \\
\text { water source }\end{array}$ & Yes & & Yes & & Yes & & Yes & \\
\hline pseudo $r^{2}$ & 0.259 & & 0.294 & & 0.294 & & 0.239 & \\
\hline
\end{tabular}

ing multiple measures; the results from one category of measures do not apply to other categories. Similarly, growers with a college degree have lower intensity of adoption of augmentation measures, but higher intensity of adoption of irrigation measures.

\section{Summary and Conclusions}

This survey showed that ample room exists for increased adoption of drought adaptation measures among Florida vegetable growers. In particular, adoption rates of augmentation and loss reduction measures have much room for increase. Additionally, while all of these measures could be used in conjunction with each other, most growers are not adopting multiple measures, particularly within categories. This could be due to financial constraints or a perception that the measures are substitutes instead of complements. In some instances, adoption of one measure decreases the marginal benefit of adopting another, such as tailwater recovery with micro-irrigation. However, for others, such as soil moisture sensors and automatic irrigation, adoption of the former would have a positive effect on the marginal benefit from adopting the latter. In other instances, the measures are completely independent, such as land leveling and alternative freeze protection. Thus, in most cases, growers could benefit from adopting multiple measures. Florida currently operates 12 mobile irrigation labs that serve 66 counties (FDACS 2013), which could be broadened to consider all possible drought adaptation measures and educate growers about possible complementarities and synergies possible through the adoption of multiple measures. Demonstration farms that implement a wide array of practices could further illustrate the benefits of adopting multiple measures. Additionally, a subsidy or rebate program could be implemented that would require investment in multiple technologies to receive payment.

While land tenure, or lack thereof, is often considered an impediment to conservation investments, we do not find consistent evidence of that here. Renting negatively affects the adoption of tailwater recovery and weather stations, but actually positively affects adoption of mulch, land leveling, and alternative freeze protection measures. A tailwater recovery system would be constructed to fit a specific field and weather stations have installation time costs, making these investments potentially less beneficial on a field for which the grower does not have land tenure. Short-term investments like mulch and mobile freeze protection investments like heaters and wind machines do not entail a large loss if the lease ends, and consequently are more likely to be adopted by renters. This indicates a need for drought adaption measures that do not entail a lost investment at the end of a lease and a need for renter-specific incentives for investments that are long term and field specific.

Similarly, we might hypothesize that education is correlated with adoption of various adaptation measures, either due to increased awareness about potential problems or 
Table 11

Intensity of adoption of augmentation, loss reduction, and irrigation planning.

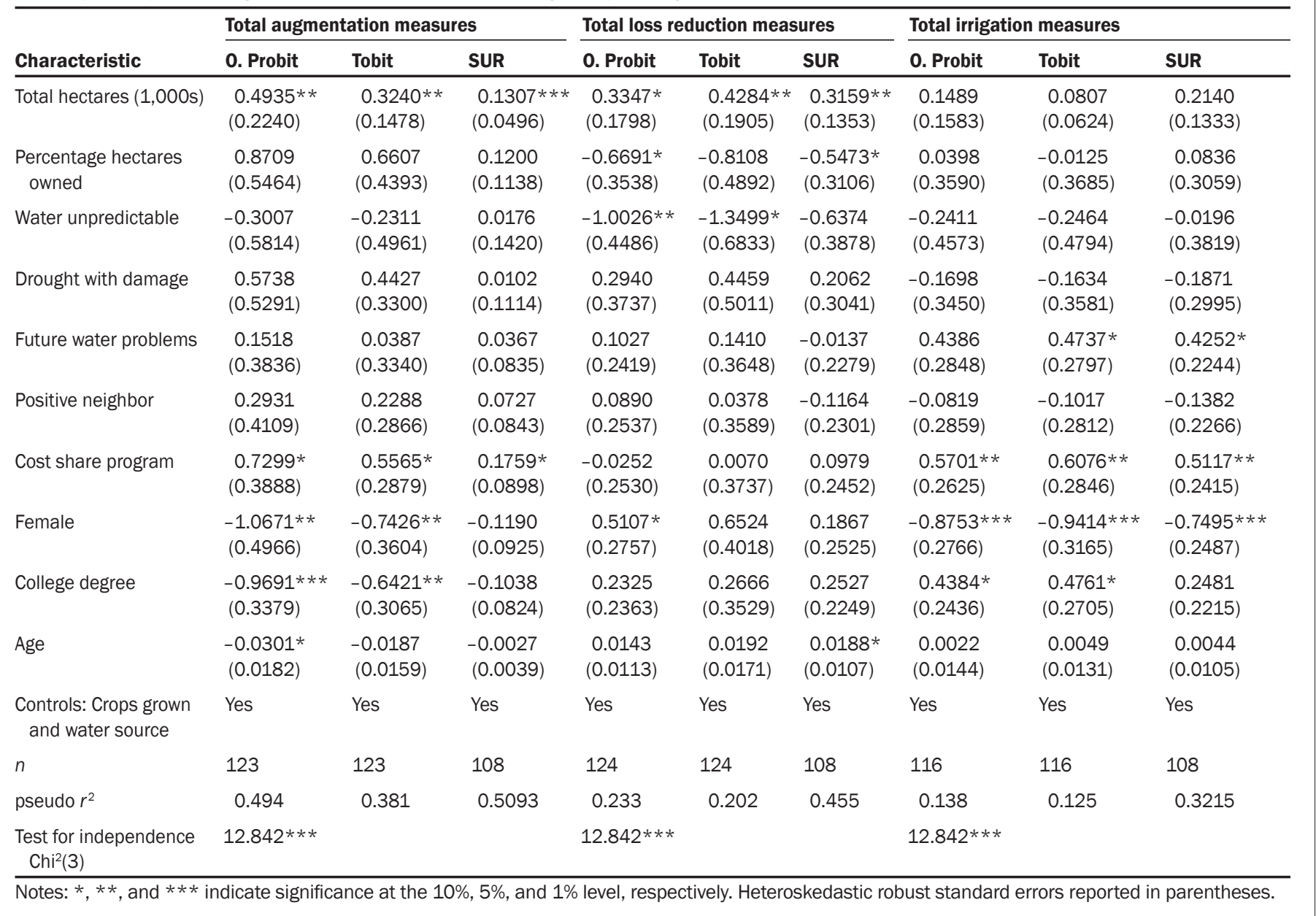

increased ease of adoption of new methods and technologies. While this is true for the adoption of mulch, leveling, alternative freeze protection measures, and variable rate irrigation, those with a college degree actually had a lower intensity of adoption of augmentation measures. This could be due to a focus on more technologically advanced measures, but these measures are not necessarily more effective at conserving water in times of drought than measures like tailwater recovery. For measures that require substantial knowledge to adopt, such as variable rate and timing of irrigation, free or subsidized training programs could encourage increased adoption.

The lower adoption rates and intensity of adoption observed among female growers merits consideration. We compared the summary statistics across genders and only found two significant differences. Female respondents are more likely to report an unpredictable water supply, with $21 \%$ of women reporting it unpredictable and only $9 \%$ of men reporting it as such. In terms of area, males manage an aver- age of 416 ha $(1,028 \mathrm{ac})$, while females manage an average of 82.5 ha $(204 \mathrm{ac})$. However, the models include controls for these factors, so these differences should not affect the results. It is possible that women are more risk averse when adopting new technology or perhaps training and marketing target male growers since they are the majority of growers. To improve adoption rates among female growers, educational materials and training that target females could be used. Female-specific growers associations might also help disseminate information and encourage adoption of measures.

Next, while we hypothesized that the variables pertaining to drought experiences, water supply predictability, and future water supply availability would be strong determinants of adoption, they were often insignificant. An unpredictable water supply is actually associated with a decrease in adoption of tailwater recovery and microirrigation. Past drought damage increases adoption of rainwater harvesting, but decreases adoption of automatic irrigation systems, and is insignificant elsewhere. Lastly, the perception of future water problems only increases adoption of tailwater recovery and weather stations, and decreases adoption of rainwater harvesting. The latter effect could be due to a perception of decreased rainfall in the future, reducing potential benefits of investing in harvesting technology. Overall, even though some growers have experienced damage or expect to face water shortages, these growers are not more likely to mitigate these factors. This could be due to a perception that possible mitigating measures do not provide enough mitigation benefit to warrant their cost. Additionally, if they believe droughts happen infrequently, the expected benefit over many seasons may seem small. However, increased frequency and severity of droughts in the future may change this benefit calculation.

On the positive side, cost share programs are associated with higher intensity of adoption of augmentation and irrigation planning measures. Such programs relieve 
financial constraints and provide incentives for adoption of beneficial technology, whether pertaining to drought adaptation or otherwise. Additional cost share programs or increased participation in current programs could result in higher rates of adoption.

Our results indicate that there are no overarching explanatory factors determining who adopts a given practice and who does not. For each adaptation measure, a unique combination of factors positively or negatively affects adoption. To encourage increased adoption, each measure must be considered individually. The same likely holds true across broader geographic regions and crops; results from a single study may not be easily extrapolated to other contexts.

In terms of Florida's future water demand and supply, these results have mixed implications. The highest rates of adoption pertain to various irrigation-related measures, pointing to the success of efforts like the mobile irrigation labs. However, at most, about half of all respondents had adopted a given measure. Additionally, about $65 \%$ of irrigated hectares relied on surface water, which is more variable in times of drought than groundwater. If demand for water increases, and water supply becomes more variable, current adoption rates of drought adaptation measures will place higher than necessary pressure on demand for water and may leave growers more vulnerable to water supply shocks. Increased adoption of a variety of drought adaptation measures would help reduce risk and overall demand for water in the state.

\section{Acknowledgements}

The authors would like to thank the survey respondents and the University of Florida for funding.

\section{References}

An, H., and L.J. Butler. 2012. A discrete-time duration analysis of technology disadoption: The case of rbST in California. Canadian Journal of Agricultural Economics 60:495-515

Baumgart-Getz, A., L.S. Prokopy, and K. Floress. 2012. Why farmers adopt best management practice in the United States: A meta-analysis of the adoption literature. Journal of Environmental Management 96:17-25.

Bielinski, M.S., T. Salame, A. Whidden, and D. Moore. 2011. Current research on freeze protection for strawberry and blueberry production. http://gcrec.ifas.ufl.edu/ static/docs/pdf/PAInet/english/SB-and-BB-freezeprotection-Fla-Ag-Expo-2011.pdf.

Carey, J.M., and D. Zilberman. 2002. A model of investment under uncertainty: Modern irrigation technology and emerging markets in water. American Journal of Agricultural Economics 84(1):171-183.

Carman, D. 2005. Tailwater Recovery. SERA-17. http:// www.sera17.ext.vt.edu/Documents/BMP_tailwater.pdf.

Caswell, M., and D. Zilberman. 1985. The choices of irrigation technologies in California. American Journal of Agricultural Economics 67(2):224-234.

Cooper, J.C., and R.W. Keim. 1996. Incentive payments to encourage farmer adoption of water quality protection practices. American Journal of Agricultural Economics 78:54-64.

De Pascale, S., L.D. Costa, S. Vallone, G. Barbieri, and A. Maggio. 2011. Increasing water user efficiency in vegetable crop production: From plant to irrigation systems efficiency. HortTechnology 21(3):301-308.

Delonge, K., A.L. Kaleita, and K.R. Thorp. 2007. Simulating the effects of spatially variable irrigation on corn yields, costs, and revenue in Iowa. Agricultural Water Management 92:99-109.

Dillman, D.A. 1991. The design and administration of mail surveys. Annual Review Sociology 17:225-249.

Dinar, A., M. Campbell, and D. Zilberman. 1992. Adoption of improved irrigation and drainage reduction technologies under limiting environmental conditions. Environmental and Resource Economics 2(4):373-398.

Dorfman, J.H. 1996. Modeling multiple adoption decisions in a joint framework. American Journal of Agricultural Economics 78(3):547-557.

Dukes, M.D., L. Zotarelli, and K.T. Morgan. 2010. Use of irrigation technologies for vegetable crops in Florida. HortTechnology 20:133-142.

FDACS (Florida Department of Agriculture and Consumer Services). 2005. Water Quality/Quantity Best Management Practices for Florida Vegetable and Agronomic Crops.http://www.freshfromflorida.com/ Divisions-Offices/Agricultural-Water-Policy/ Enroll-in-BMPs/BMP-Rules-Manuals-andOther-Documents.

FDACS. 2013. Evaluate your irrigation system. http:// www.freshfromflorida.com/Divisions-Offices/ Agricultural-Water-Policy / Evaluate-YourIrrigation-System.

FDEP (Florida Department of Environmental Protection). 2014. Consumptive use permitting consistency. http:// www.dep.state.fl.us/water/waterpolicy/docs/cupcon/ ag_cupcon_051712.pdf.

FDEP. 2009. Florida drought conditions. http://www.dep. state.fl.us/Drought/.

FDEP. 2011. Water resource caution areas. http://www.dep. state.fl.us/water/reuse/wrca.htm.

Freeman, J.H., G.E. Vallad, G. Liu, E.H. Simonne, G.J. Hochmuth, M.D. Dukes, L. Zotarelli, J.W. Noling, D.A. Botts, P.J. Dittmar, and S.A. Smith. 2014. Vegetable Production Handbook for Florida. In Vegetable \& Small Fruit Production Handbook for Florida 2014-2015, eds. G.E. Vallad, J.H. Freeman, and P.J. Dittmar. 2014. Gainesville: University of Florida Institute of Food and
Agricultural Sciences EDIS document \#VPH http:// edis.ifas.ufl.edu/pdffiles/cv/cv10000.pdf.

Goodhue, R.E., D.M. Heien, H. Lee, and D.A. Sumner. 2002. Grower-winery contracts in California: Use and design. California Agriculture 56(3):97-102.

Green, G., D. Sunding, D. Zilberman, and D. Parker. 1996. Explaining irrigation technology choices: A microparameter approach. American Journal of Agricultural Economics 78(4):1064-1072.

Griliches, Z. 1957. Hybrid corn: An exploration in the economics of technological change. Econometrica 25(4):501-522.

Grogan, K.A., and R.E. Goodhue. 2012. Spatial externalities of pesticide control decisions in the California citrus industry. Journal of Agricultural and Resource Economics 37(1):156-179.

He, X., H. Cao, and L. Feng-Min. 2007. Econometric analysis of the determinants of adoption of rainwater harvesting and supplementary irrigation technology (RHSIT) in the semiarid Loess Plateau of China. Agricultural Water Management 89(3):243-250.

Karl, T.R., J.M. Melillo, and T.C. Peterson. (Eds.). 2009. Global Climate Change Impacts in the United States. New York: Cambridge University Press.

Knowler, D., and B. Bradshaw. 2007. Farmers' adoption of conservation agriculture: A review and synthesis of recent research. Food Policy 32:25-48.

Koundouri, P., C. Nauges, and V. Tzouvelekas. 2006. Technology adoption under production uncertainty: Theory and application to irrigation technology. American Journal of Agricultural Economics 88(3):657-670.

Leib, B.G., M. Hattendorf, T. Elliott, and G. Matthews. 2002. Adoption and adaptation of scientific irrigation scheduling: Trends from Washington, United States as of 1998. Agricultural Water Management 55(2):105-120.

Locascio, S.J. 2005. Management of irrigation for vegetables: Past, present, and future. Hort Technology 15:482-485.

Lyrene, P., and J. Williamson. 2004. Protecting blueberries from freezes in Florida. University of Florida Electronic Data Information Source (EDIS) document HS968.

Marella, R.L. 2008. Water Use in Florida, 2005 and Trends 1950-2005. US Department of the Interior, US Geological Survey.

Morris, M. 2006. Soil moisture monitoring: Low-cost tools and methods. ATTRA-National Sustainable Agriculture Information Service. www.attra.ncat.org/attra-pub/ PDF/soil_moisture.pdf.

Moss,B.2013.Apple farmers hear wind machine benefits against spring freeze. http://www.hendersonvillelightning. com/business/1215-apple-farmers-hear-wind-machinebenefits-against-spring-freeze.html.

Munoz-Carpena, R., J.H. Crane, G.D. Israel, and C. Yurgalevitch. 2003. Water conservation survey of Miami-Dade County agricultural and golf course commercial water users. Proceedings of the Florida State Horticultural Society 116:15-21. 
Naidu, S. 2008. International Encyclopaedia of Agricultural Science and Technology: Soils and Composts. New Delhi: Mittal.

NCDC (National Climatic Data Center). 2011. NOAA's 1981-2010 Climate Normals. http://www1.ncdc.noaa. gov/pub/data/normals/1981-2010/.

Öztekin, T. 2013. Short-term effects of land leveling on irrigation-related soil properties in a clay loam soil Scientific World Journal 187490.

Parsons, L.R., and B.J. Boman. 2013. Microsprinkler irrigation for cold protection of Florida citrus. University of Florida EDIS document HS931.

Ramakrishna, A., H.M. Tam, S.P. Wani, and T.D. Long. 2006. Effect of mulch on soil temperature, moisture, weed infestation, and yield of groundnut in Northern Vietnam. Field Crops Research 95:115-125.

Reyes-Cabrera, J., L. Zotarelli, D.L. Rowland, M.D. Dukes, and S.A. Sargent. 2014. Drip as alternative irrigation method for potato in Florida sandy soils. American Journal of Potato Research 91:504-516.

Rogers, E.M. 1976. New product adoption and diffusion. Journal of Consumer Research 2(4):290-301.

Rogers, J., T. Borisova, J. Ullman, K. Morgan, L. Zotarelli, and K. Grogan. 2014. Factors affecting the choice of irrigation systems for Florida tomato production. University of Florida EDIS document FE960.

Schaible, G., and M. Aillery. 2012. Water conservation in irrigated agriculture: Trends and challenges in the face of emerging demands. USDA Economic Information Bulletin No. EIB-99. http://www.ers.usda.gov/ publications/eib-economic-information-bulletin/ eib99.aspx\#. Un_ghvlwo9Q.

Schuck, E.C., W.M. Frasier, R.S. Webb, L.J. Ellington, and W.J. Umberger. 2005. Adoption of more technically efficient irrigation systems as a drought response. Water Resources Development 21(4):651-662.

Shortt, R., and A. Verhallen. 2011. Monitoring Soil Moisture to Improve Irrigation Decisions. http:// www.omafra.gov.on.ca/english/engineer/facts/11037.htm\#t1.

Shrefler, J., and L. Brandenberger. 2014. Use of plastic mulch and row covers in vegetable production. Oklahoma Cooperative Extension Service Document HLA-6034.

Simonne, E., R. Hochmuth, J. Breman, W. Lamont, D. Treadwell, and A. Gazula. 2008. Drip-irrigation systems for small conventional vegetables farms and organic vegetable farms. University of Florida EDIS document HS1144.

Smajstria, A.G., B.J. Boman, D.Z. Clark, D.S. Harrison, F.T. Izuno, D.J. Pitts, and F.S. Zazueta. 2002. Efficiencies of Florida agricultural irrigation systems. Institute of Food and Agricultural Sciences, University of Florida Electronic Data Information Source Document BUL247.

Smith, S.K., and S. Rayer. 2013. Projections of Florida population by county, 2015-2040, with estimates for
2012. Bureau of Economic and Business Research, University of Florida 46(165):1-8.

Soule, M.J., A. Tegene, and K.D. Wiebe. 2000. Land tenure and the adoption of conservation practices. American Journal of Agricultural Economics 82(4):993-1005.

SWFWMD (Southwest Florida Water Management District). 2010. Mini-FARMS Handbook. http:// www.swfwmd.state.fl.us/agriculture/mini_farms.php.

Texas Water Development Board (2005). Water Conservation Best Management Practices (BMP) Guide for Agriculture in Texas. http://www.tsswcb.texas.gov/files/docs/ waterconservation/water_conservation_bmp.pdf.

Thessler, S., L. Kooistra, F. Teye, H. Huitu, and A. Bregt. 2011. Geosensors to support crop production: Current applications and user requirements. Sensors (Basel) 11(7):6656-6684.

USDA (US Department of Agriculture). 2014. Farm and Ranch Irrigation Survey (2013). 2012 Census of Agriculture. Document AC-12-SS-1.

USDA NASS (National Agricultural Statistics Service). 2012. Census of agriculture.

USDA NRCS (Natural Resources Conservation Services). 2014. Environmental Quality Incentives Program. http://www.nrcs.usda.gov/wps/portal/nrcs/detail/fl/ programs/?cid=nrcs141p2_014954.

Williamson, J.G., P.M. Lyrene, and J.W. Olmstead. 2012 Protecting blueberries from freezes in Florida. http:// edis.ifas.ufl.edu/hs216. 